Original article

\title{
Are nurse presenteeism and patient safety culture associated: a cross-sectional study
}

\author{
Hana Brborović1, Ognjen Brborović ${ }^{2}$, Vlatka Brumen ${ }^{3}$, Gordana Pavleković2 , and Jadranka \\ Mustajbegović ${ }^{1}$
}

Department of Occupational Health and Sports Medicinel, Department of Social Medicine and Organization of Health Care2, University of Zagreb School of Medicine, Andrija Štampar School of Public Health, Department of Managerial Systems \& Occupational Environment ${ }^{3}$, University of Applied Health Studies, Zagreb, Croatia

Received in November 2013

CrossChecked in November 2013

Accepted in April 2014

\begin{abstract}
Working as a nurse involves great dedication and sacrifice: working night shifts, working overtime, and coming to work sick. The last is also known as presenteeism. Research has shown that poor nurse performance can affect both caregiver's and patient's safety. The aim of this cross-sectional study was to investigate whether nurse presenteeism affected patient safety culture and to look deeper into the characteristics of nurse presenteeism and patient safety culture in Croatia. The study was conducted in one general hospital in Croatia over April and May 2012 and specifically targeted medical nurses as one of the largest groups of healthcare professionals. They were asked to fill two questionnaires: the six-item Stanford Presenteeism Scale (SPS-6) and the Hospital Survey on Patient Safety Culture (HSOPSC). We found no association between presenteeism and patient safety culture. Overall positive perception of safety was our sample's strength, but other dimensions were positively rated by less than $65 \%$ of participants. The lowest positive response concerned "nonpunitive response to error", which is consistent with previous studies. Presenteeist nurses did not differ in their characteristics from nurses without presenteeism (gender, age, years of experience, working hours, contact with patients and patient safety grades). Our future research will have to include a broader healthcare population for us to be able to identify weak spots and suggest improvements toward high-quality and cost-effective health care.
\end{abstract}

KEY WORDS: Hospital Survey on Patient Safety Culture; occupational health; sickness; Stanford Presenteeism Scale

Working as a nurse involves great dedication and sacrifice: working night shifts, working overtime, and coming to work sick. The last is also known as presenteeism. Presenteeism implies limited job performance due to a health problem (1-4). Research has shown that in occupations such as nursing, poor performance at work can have serious consequences for patient safety (5-7). Patient safety culture (PSC) is a set of individual and group values, attitudes, perceptions, competencies, and behavioural patterns towards health and safety (8). The World Health
Organization (WHO) has described PSC in five points: 1) all healthcare workers accept responsibility for the safety of themselves, their co-workers, patients, and visitors; 2 ) patient safety is a priority above financial and operational goals; 3 ) identification, communication, and resolution of safety issues are encouraged and rewarded; 4) learning from accidents without people being blamed; 5) appropriate resources, structure, and accountability are provided to maintain effective safety systems (9). We can say that PSC is actually a prerogative for patient safety. Studies have shown that 
up to $16.6 \%$ of patients in acute care hospitals experience one or more adverse events (10-17) that are harmful or potentially harmful such as incorrect or late diagnosis, prescribing and medication, loss of medical documentation during patient's transfer, errors in postoperative treatment, errors in the application of medical devices (such as needlestick injuries) (18). When adverse events do not cause death or permanent damage to health, they lead to extended stays at the hospital and higher cost of treatment $(19,20)$.

There are 30,000 trained nurses in Croatia, 7,000 of whom hold a diploma degree. Most work in public health care.

Previous research has shown that healthcare workers are at increased risk of working sick and that teachers and nurses have the highest rates of presenteeism related to chronic diseases (21-23). Letvak et al. (6) showed that nurse presenteeism was associated with an increase in medication errors and patient falls, as well as with poorer self-reported quality of care. A systematic review by Gartner et al. (7) showed that chronic mental diseases, which are often a cause of presenteeism, were negatively associated with patient safety.

However, little is known about presenteeism among nurses in Croatia, hospital nurses in particular. The aim of our study was to get a glimpse into presenteeism rates among Croatian hospital nurses and see if their presenteeism affects patient safety.

\section{PARTICIPANTS AND METHODS}

This cross-sectional study included 148 nurses (of 194 invited) from the general hospital in Požega, Croatia. The hospital was selected based on a convenience sample of registered nurses. As the study was conducted in April and May 2012 while the first investigator attended postgraduate studies at the Zagreb University School of Medicine, we obtained an approval from the School's Ethics Committee as well as from the hospital's review board. All participants signed informed consents.

\section{Survey and data collection}

In this study we used two questionnaires: the sixitem Stanford Presenteeism Scale (SPS-6) and the Hospital Survey on Patient Safety Culture (HSOPSC). Both were translated into Croatian by one translator for each questionnaire and then back-translated into
English by an independent translator for each questionnaire, who was blinded to the original questionnaire.

The SPS-6 questionnaire consists of six items through which the nurses were asked to evaluate their performance in the face of a health problem (33) using a Likert scale from 1 to 5 , where 1 corresponds to strong disagreement and 5 to strong agreement with the statement. Scores for items 1, 3, and 4 are then reversed, so that score 1 equals 5,2 equals 4 , and so on. The sum of all scores can range from 6 to 30 . Higher scores indicate better performance at work (24). For statistical analysis however, we needed a clear cut-off score, to divide respondents into groups whose performance was affected by presenteeism and those whose performance was not affected. Accordingly, we set cut-off score for presenteeism in the lower quartile, which was 18 . Furthermore, in a personal communication, the main author of SPS-6 also suggested 18 as a cut-off score (25).

The second, HSOPSC, questionnaire is a selfreporting tool used worldwide for assessing safety culture in hospitals (8). It has shown moderate-tostrong validity and reliability (26). The results of psychometric analyses for the Croatian version of HSOPSC have been presented and discussed elsewhere (27). Our translation of the US questionnaire consists of 42 items grouped in 12 dimensions and two single-item measures. Eight dimensions measure PSC at unit level, two at hospital level, and two are outcome measures. For three of the 12 dimensions frequency is reported on a five-point scale from "never" to "always", whereas for the remaining nine dimensions agreement with the statement is reported on a five-point Likert scale from "strongly disagree" to "strongly agree". Safety grade is a single-item evaluation of patient safety in the nurse's unit and is scored on a scale from A to F, where higher score indicates higher patient safety level. The second single item measures the frequency of adverse event reports filed by the respondents over the past 12 months, and is scored as follows: no adverse event reports - 0 points; 1 to 2 reports - 1 point; 3 to 5 reports - 2 points; 6 to 10 reports -3 points, 11 to 20 reports -4 points, and 21 or more reports -5 points.

The questionnaires were distributed to the nurses at weekly educational meetings and the responses were anonymous. 


\section{Statistical analysis}

For all analyses, statistical significance was set at the $p$ value of $<0.05$. Normality of distribution was tested using the Kolmogorov-Smirnov normality test. Descriptive analysis included participants' age, SPS-6 score, years of working experience, the number of working hours, direct contact with the patients, and the number of reported adverse events. Binary logistic regression was used to establish whether presenteeism was associated with patient safety culture. The results were adjusted for age, sex, department, years of working experience, number of working hours a week and direct contact with patients. ANOVA was used to compare SPS-6 scores across departments. Fisher's exact test was used to compare general characteristics between the participants above and below the cut-off score. Analysis was performed using the SAS version 9.1.3 (SAS Institute Inc., SAS Campus Drive, Cary, NC, USA), and data were processed using the Microsoft Excel Data Entry and Reporting Tool (Microsoft Corporation, Mountain View, CA, USA).

\section{RESULTS AND DISCUSSION}

Of 194 distributed questionnaires 148 were completed and analysed. Age distribution was not normal [Kolmogorov-Smirnov test, $\mathrm{D}(139)=0.178$, $p<0.001]$ and its median was $45 \pm 9.24$ years (range: $22-59$ years). SPS-6 total scores were normally distributed $[\mathrm{D}(150)=0.094, p=0.58$; KolmogorovSmirnov test] with the mean of $21.3 \pm 4.58$ and range between 7 and 30. Across hospital departments, mean SPS-6 scores were all above the cut-off score of 18 , suggesting that presenteeism was not departmentspecific [Table 1; differences not statistically significant $\mathrm{F}(6,143)=1.77, p=0.109$, ANOVA].

Table 2 shows that the participants divided along the SPS-6 cut-off score did not differ in gender, age, years of experience, working hours, or contact with patients $(p<0.05)$.

Binary logistic regression in nurses with SPS-6 score 18 and lower showed no association with patient safety culture [chi-square $(11)=8.93, p=0.628$ ]. Nurses having the SPS-6 score below the cut-off did not significantly differ in patient safety grades from the nurses scoring 19 and above [chi-square $(3)=1.64$, $p=0.66]$ (Figure 1).

Even though the overall positive perception of "in-hospital patient transfer" and safety were our sample's strength, other dimensions had positive responses below $65 \%$. The lowest positive response rate concerned "nonpunitive response to error", which is consistent with other studies (Figure 2) $(28,29)$. This may be due to the perception that errors shall be punished (so called cultural blame), as lower error rates are seen in units with less positive climate (29, 30). The same goes for the dimension "feedback and communication about error" and "frequency of adverse reporting" $(28,29)$. The questionnaire also confirmed the perception that hospitals in Croatia are understaffed with nurses. This perception coincides with the public perception, as hospital understaffing with healthcare personnel, nurses and physicians in particular, has been a burning issue in the country for at least 20 years. Our findings on hospital management support for patient safety indirectly corroborate earlier studies with medical nurses, in which poor work organisation had been recognised as stressful and therefore a predictor of low performance at work (31, 32).

\section{Limitations of this study and the questionnaires}

This study had several limitations. We are aware that the convenient sample and the relatively small number of participating nurses may have biased the results so that they can not be generalised. However, we feel that this convenience sample can represent an average hospital in Croatia. Our results may be biased

Table 1 Mean SPS-6 scores obtained across hospital departments

\begin{tabular}{ccccccccc} 
& \multicolumn{7}{c}{ Departments } \\
\cline { 2 - 8 } & Surgery & $\begin{array}{c}\text { Non- } \\
\text { surgery }\end{array}$ & Paediatrics & Obstetrics & Psychiatry & Anaesthesiology & ICU \\
\hline Respondents & 43 & 48 & 16 & 12 & 7 & 7 & 15 \\
\hline $\begin{array}{c}\text { Mean SPS-6 } \\
\text { score }\end{array}$ & 21.42 & 21.04 & 23 & 18.62 & 22.86 & 18.43 & 22.53 \\
\hline$( \pm$ SD) & $(4.76)$ & $(4.41)$ & $(3.31)$ & $(4.81)$ & $(5.05)$ & $(2.55)$ & $(4.32)$ \\
\hline
\end{tabular}

Non-surgical departments included internal medicine and neurology

ICU - Intensive Care Unit 
Table 2 General characteristics of the participants with SPS-6 score 18 or lower and higher than 18

\begin{tabular}{|c|c|c|}
\hline & \multicolumn{2}{|c|}{ SPS-6 SCORE } \\
\hline & $>18$ & $\leq 18$ \\
\hline Men & 13 & 5 \\
\hline Women & 97 & 33 \\
\hline Total $(\mathrm{N})$ & 110 & 38 \\
\hline Median age & 45 & 47 \\
\hline \multicolumn{3}{|l|}{ Years of working experience } \\
\hline 1 to 5 years & 11 & 4 \\
\hline 6 to 10 years & 16 & 3 \\
\hline 11 to 15 years & 19 & 7 \\
\hline 16 to 20 years & 17 & 5 \\
\hline 21 years or more & 47 & 15 \\
\hline Total $(\mathrm{N}, \%)$ & $110(74.3 \%)$ & $38(25.7 \%)$ \\
\hline \multicolumn{3}{|l|}{ Number of working hours } \\
\hline Less than 20 hours per week & 2 & 0 \\
\hline 20 to 39 hours per week & 4 & 5 \\
\hline 40 to 59 hours per week & 100 & 32 \\
\hline 60 to 79 hours per week & 2 & 1 \\
\hline 80 to 99 hours per week & 1 & 0 \\
\hline 100 hours per week or more & 1 & 0 \\
\hline Total $(\mathrm{N}, \%)$ & $110(74.3 \%)$ & $38(25.7 \%)$ \\
\hline \multicolumn{3}{|c|}{ Direct interaction or contact with patients } \\
\hline Yes & 4 & 0 \\
\hline No & 106 & 38 \\
\hline Total $(\mathrm{N}, \%)$ & $110(74.3 \%)$ & $38(25.7 \%)$ \\
\hline
\end{tabular}

by the small number of presenteeist nurses. We chose the four-week period in the spring because it is usually not the time when working population takes a vacation but save it for the holiday season or the summer. We expected our population to be well in their working routine and perhaps experiencing their acute or chronic health problems. We also expected that the four-week frame would suffice to recruit enough participants who had experienced presenteeism and still be able to recall these experiences (24). It is however true that if we asked them to refer to a longer time frame, responses may have been different, but this would be departing from SPS-6.

The authors of the SPS-6 questionnaire acknowledge that work experiences in the past month may be affected by many environmental as well as personal factors and may change from time to time (24). Due to these factors we may not have recruited all respondents who have experienced presenteeism over the last month.
Our research was anonymous to make participants as comfortable with responding honestly as possible. However, it is possible that some of our participants were not fully honest and that some nurses who had experienced presenteeism in the previous month did not wish to respond because they did not feel comfortable with telling the truth. Another limitation is that answering to HSOPSC may be tiring, and respondents may lose interest and answer questions offhandedly (33).

For this reason we decided that another questionnaire which examines health problems, along with SPS-6 questionnaire would be too timeconsuming and negatively affect the response rate. However, our future research should go into that direction. Another reason why we opted not to investigate specific health issues which had led to presenteeism is that research done so far has already provided a good insight on this subject in the field of nursing $(4,21-23,34-37)$. 


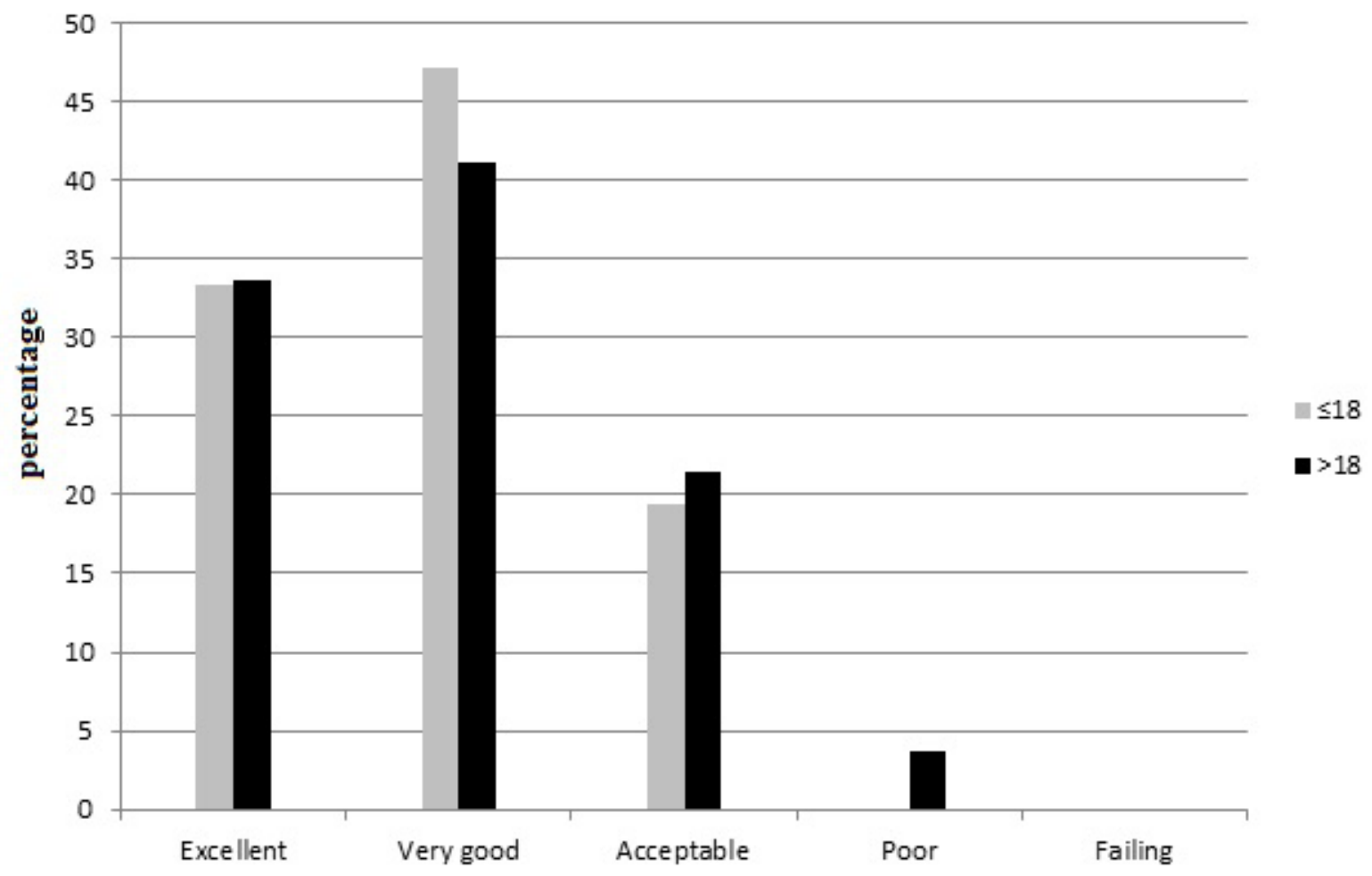

Figure 1 Distribution of patient safety grades between presenteeists (SPS-6 score $\leq 18)$ and non-presenteeists (SPS-6 score $>18$ )

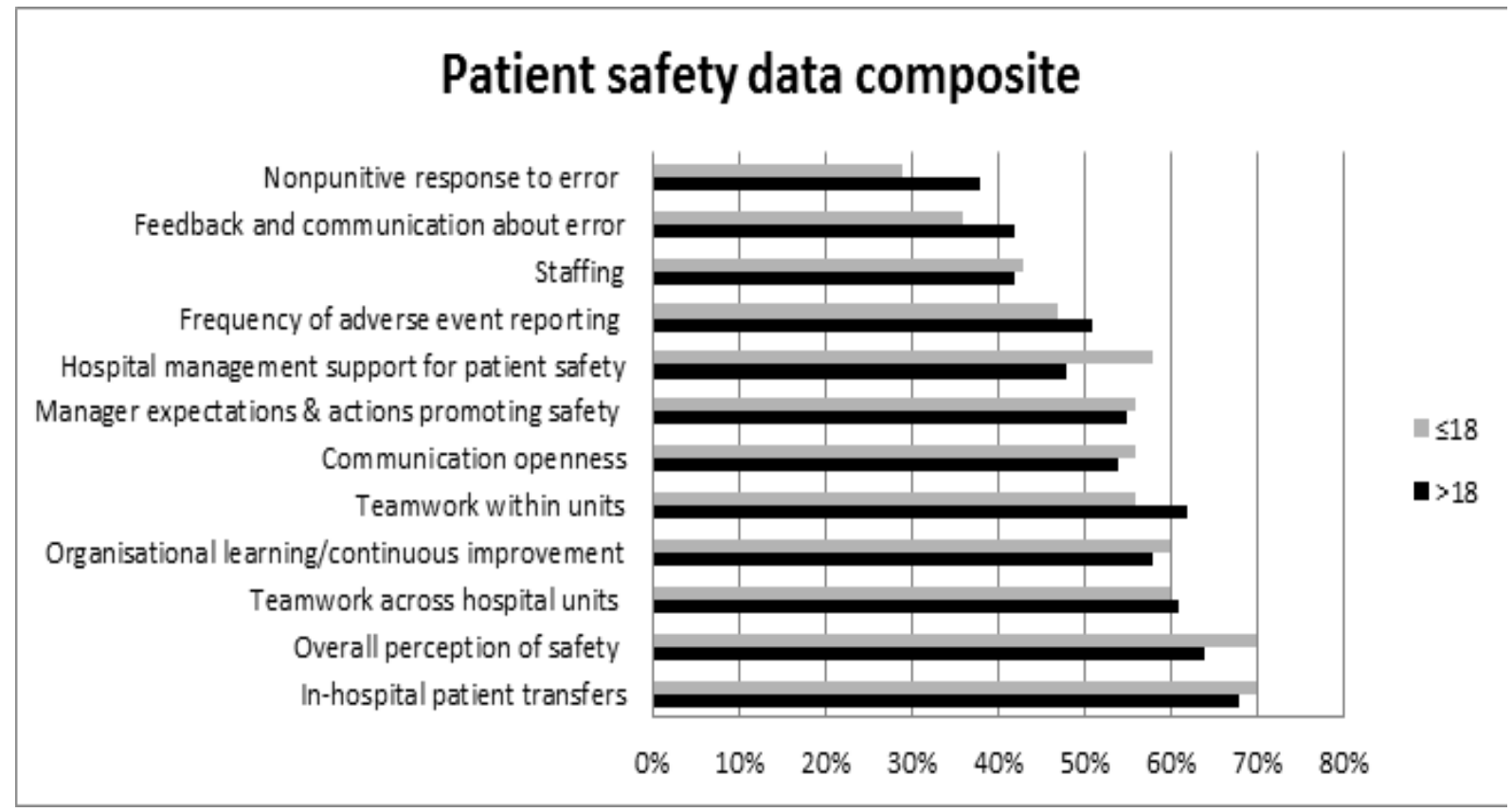

Figure 2 Patient safety culture rating by presenteeists (SPS-6 score $\leq 18)$ and non-presenteists (SPS-6 score >18) 
We also acknowledge that HSOPSC measures patient safety culture of the department or the hospital and that it may not relate to presenteeism of individual nurse, whereas SPS-6 is an individual measure. To overcome this limitation we reported our results at the department level.

Tools employed in this research were used "as is", i.e. in their original format to screen the target population, in an attempt to identify weak spots, but have not succeeded in it.

Our future research will therefore have to include a broader healthcare population for us to be able to identify the weak spots and suggest improvements toward high-quality and cost-effective health care.

\section{Conflict of interest}

None to declare.

\section{Acknowledgements}

We wish to thank all the participants in this study. This study was funded from the project "Health at the workplace and healthy working environment" (approved by the Ministry of Science, Education and Sports under grant no. 108-1080316-0300).

\section{REFERENCES}

1. Loeppke R, Hymel PA, Lofland JH, Pizzi LT, Konicki DL, Anstadt GW, Baase C, Fortuna J, Scharf T; American College of Occupational and Environmental Medicine. Health-related workplace productivity measurement: general and migrainespecific recommendations from the ACOEM Expert Panel. J Occup Environ Med 2003;45:349-59. PMID: 12708138

2. Burton WN, Conti DJ, Chen CY, Schultz AB, Edington DW The role of health risk factors and disease on worker productivity. J Occup Environ Med 1999;41:863-77. PMID: 10529942

3. Chapman LS. The art of health promotion. Am J Health Promot 2005;19:TAHP-1-12. doi: 10.4278/0890-117119.3.TAHP-1

4. SchultzAB, Edington DW. Employee health and presenteeism: a systematic review. J Occup Rehabil 2007;17:547-79. PMID 17653835

5. Gärtner FR, Nieuwenhuijsen K, van Dijk FJH, Sluiter JK Impaired work functioning due to common mental disorders in nurses and allied health professionals: the Nurses Work Functioning Questionnaire. Int Arch Occup Environ Health 2012;85:125-38. doi: 10.1007/s00420-011-0649-0

6. Letvak SA, Ruhm CJ, Gupta SN. Nurses' presenteeism and its effects on self-reported quality of care and costs. Am J Nurs 2012;112:30-8. doi: 10.1097/01.NAJ.0000411176.15696. f9

7. Gärtner FR, Nieuwenhuijsen K, Van Dijk FJH, Sluiter JK. The impact of common mental disorders on the work functioning of nurses and allied health professionals: a systematic review. Int J Nurs Stud 2010;47:1047-61. doi: 10.1016/j.ijnurstu.2010.03.013

8. Nieva VF, Sorra J. Safety culture assessment: a tool for improving patient safety in healthcare organizations. Qual Saf Health Care 2003;12(Suppl 2):ii17-23. PMID: 14645891

9. WHO. Definitions of Key Concepts from the WHO Patient Safety Curriculum Guide (2011) [displayed 10 April 2014]. Available at http://www.who.int/patientsafety/education/ curriculum/course1a_handout.pdf

10. Brennan TA, Leape LL, Laird NM, Hebert L, Localio AR, Lawthers AG, Newhouse JP, Weiler PC, Hiatt HH. Incidence of adverse events and negligence in hospitalized patients. Results of the Harvard Medical Practice Study I. N Engl J Med 1991;324:370-76. doi: 10.1056/NEJM199102073240604

11. Davis P, Lay-Yee R, Briant R, Ali W, Scott A, Schug S. Adverse events in New Zealand public hospitals I: occurrence and impact. N Z Med J 2002;115:U271. PMID: 12552260

12. Schiøler T, Lipczak H, Pedersen BL, Mogensen TS, Bech KB, Stockmarr A, Svenning AR, Frølich A; Danish Adverse Event Study. [Incidence of adverse events in hospitals. A retrospective study of medical records, in Danish]. Ugeskr Laeger 2001;163:5370-8. PMID: 11590953

13. Smits M, Christiaans-Dingelhoff I, Wagner C, van der Wal G, Groenewegen PP. The psychometric properties of the „Hospital Survey on Patient Safety Culture“ in Dutch hospitals. BMC Health Services Research 2008;8:230. doi: 10.1186/1472-6963-8-230

14. Thomas EJ, Studdert DM, Burstin HR, Orav EJ, Zeena T, Williams EJ, Howard KM, Weiler PC, Brennan TA. Incidence and types of adverse events and negligent care in Utah and Colorado. Med Care 2000;38:261-71. PMID: 10718351

15. Vincent C, Neale G, Woloshynowych M. Adverse events in British hospitals: preliminary retrospective record review. BMJ 2001;322:517-9. doi: 10.1136/bmj.322.7285.517

16. Wilson RM, Runciman WB, Gibberd RW, Harrison BT, Newby L, Hamilton JD. The quality in Australian health care study. Med J Aust 1995;163:458-71. PMID: 7476634

17. Zegers M, de Bruijne MC, Wagner C, Hoonhout LH, Waaijman R, Smits M, Hout FA, Zwaan L, ChristiaansDingelhoff I, Timmermans DR, Groenewegen PP, van der Wal G. Adverse events and potentially preventable deaths in Dutch hospitals: results of a retrospective patient record review study. Qual Saf Health Care 2009;18:297-302. doi: 10.1136/qshc.2007.025924

18. Gibson R, Prasad Singh J. Wall of Silence: The Untold Story of the Medical Mistakes That Kill and Injure Millions of Americans. Washington (DC): LifeLine Press; 2003.

19. Bates DW, Spell N, Cullen DJ, Burdick E, Laird N, Petersen LA, Small SD, Sweitzer BJ, Leape LL. The costs of adverse drug events in hospitalized patients. Adverse Drug Events Prevention Study Group. JAMA 1997;277:307-11. PMID: 9002493

20. National Research Council. To Err is Human: Building a Safer Health System. Washington (DC): National Academy Press; 2000.

21. Elstad JI, Vabo M. Job stress, sickness absence and sickness presenteeism in Nordic elderly care. Scand J Public Health 2008;36:467-74. doi: 10.1177/1403494808089557

22. Aronsson G, Gustafsson K, Dallner M. Sick but yet at work. An empirical study of sickness presenteeism. J Epidemiol 
Community Health 2000;54:502-9. doi: 10.1136/ jech.54.7.502

23. McKevitt C, Morgan M, Dundas R, Holland W. Sickness absence and 'working through' illness: a comparison of two professional groups. J Public Health Med 1997;19:295-300. PMID: 9347453

24. Pelletier KR, Koopman C. Bringing Health to the Bottom Line. Business and Health 2003. [displayed 10 April 2014] Available at: http://managedhealthcareexecutive. modernmedicine.com/managed-healthcare-executive/news/ bringing-health-bottom-line?page=full

25. Koopman C, Pelletier KR. Setting a Cut-off Score on the SPS-6 Scale [personal communication]. 2012.

26. Blegen MA, Gearhart S, O'Brien S, Sehgal NL, Alldredge BK. AHRQ's hospital survey on patient safety culture: psychometric analyses. J Patient Saf 2009;5:139-44. doi: 10.1097/PTS.0b013e3181b53f6e

27. Brborović H, Sklebar I, Brborović O, Brumen V, Mustajbegović J. Development of a Croatian version of the US Hospital Survey on Patient Safety Culture questionnaire: dimensionality and psychometric properties. Postgrad Med J 2014;90:125-32. doi: 10.1136/postgradmedj-2013-131814

28. Alahmadi HA. Assessment of patient safety culture in Saudi Arabian hospitals. Qual Saf Health Care 2010;19:e17. doi: 10.1136/qshc.2009.033258

29. Halbesleben JRB, Wakefield BJ, Wakefiel DS, Cooper LB. Nurse burnout and patient safety outcomes: nurse safety perception versus reporting behavior. West J Nurs Res 2008;30:560-79. doi: 10.1177/0193945907311322

30. Edmondson AC. Learning from mistakes is easier said than done: group and organizational influences on the detection and correction of human error. J Appl Behav Sci 1996;32:528. doi: $10.1177 / 0021886396321001$

31. Golubić R, Milošević M, Knežević B, Mustajbegović J. Work-related stress, education and work ability among hospital nurses. J Adv Nurs 2009;65:2056-66. doi: 10.1111/j.1365-2648.2009.05057.x

32. Milutinović D, Golubović B, Brkić N, Prokeš B. Professional stress and health among critical care nurses in Serbia. Arh Hig Rada Toksikol 2012;63:171-80. doi: 10.2478/100041254-63-2012-2140

33. Bodur S, Filiz E. Validity and reliability of Turkish version of "Hospital Survey on Patient Safety Culture" and perception of patient safety in public hospitals in Turkey. BMC Health Services Research 2010;10:28. doi: 10.1186/1472-6963-1028

34. Middaugh DJ. Presenteeism: sick and tired at work. Dermatol Nurs 2007;19:172-3, 185. PMID: 17526305

35. Marlowe JF. Depression's surprising toll on worker productivity. Empl Benefits J 2002;27:16-21. PMID: 11859537

36. Bergström G, Bodin L, Hagberg J, Lindh T, Aronsson G, Josephson M. Does sickness presenteeism have an impact on future general health? Int Arch Occup Environ Health 2009;82:1179-90. doi: 10.1007/s00420-009-0433-6

37. Kivimäki M, Head J, Ferrie JE, Hemingway H, Shipley MJ, Vahtera $\mathrm{J}$, et al. Working while ill as a risk factor for serious coronary events: the Whitehall II study. Am J Public Health 2005;95:98-102. doi: 10.2105/AJPH.2003.035873 


\section{Sažetak}

\section{Presječno ispitivanje povezanosti prezentizma i kulture bolesničke sigurnosti u medicinskih sestara}

Zanimanje medicinske sestre uključuje veliku predanost i požrtvovnost: medicinske sestre rade noćne smjene, rade prekovremeno i dolaze na posao i kada su bolesne. Naziv za ovu zadnju pojavu je prezentizam. Neka su istraživanja pokazala da smanjena radna sposobnost medicinskih sestara zbog bolesti može ugroziti sigurnost pružatelja zdravstvene usluge i bolesnika. Cilj ovog presječnog istraživanja bio je ispitati obilježja prezentizma i kulture bolesničke sigurnosti u medicinskih sestara u Hrvatskoj te utječe li njihov prezentizam na kulturu bolesničke sigurnosti. Istraživanje je provedeno u jednoj općoj bolnici u Hrvatskoj tijekom travnja i svibnja 2012., i bilo je posebno ciljano prema medicinskim sestrama s obzirom na to da čine jednu od najvećih skupina zdravstvenih djelatnika. Ispitanici su zamoljeni da ispune dva upitnika: Stanfordsku ljestvicu prezentizma (SPS-6) i Upitnik o kulturi bolesničke sigurnosti u bolnici (HSOPSC). Nije nađena povezanost između prezentizma i kulture bolesničke sigurnosti. Najveći broj pozitivnih odgovora imala je dimenzija "Opća percepcija bolesničke sigurnosti”; ostale dimenzije imale su pozitivne odgovore ispod $65 \%$. Najmanji broj pozitivnih ocjena imala je dimenzija "Nekažnjavajući pristup neželjenom događaju”, što je u skladu s prethodnim istraživanjima. U pogledu spola, dobi, godina iskustva, radnih sati, kontakata s bolesnicima i njihove sigurnosti, medicinske sestre s prezentizmom nisu se nimalo razlikovale od medicinskih sestara bez prezentizma.

KLJUČNE RIJEČI: bolest; medicina rada; Stanfordska ljestvica prezentizma; Upitnik o kulturi bolesničke sigurnosti u bolnici

\section{CORRESPONDING AUTHOR:}

Hana Brborović, MD

University of Zagreb School of Medicine

Andrija Stampar School of Public Health

Department of Environmental and Occupational Health

Rockefellerova 4, HR-10000 Zagreb, Croatia

E-mail: hana.brborovic@snz.hr 